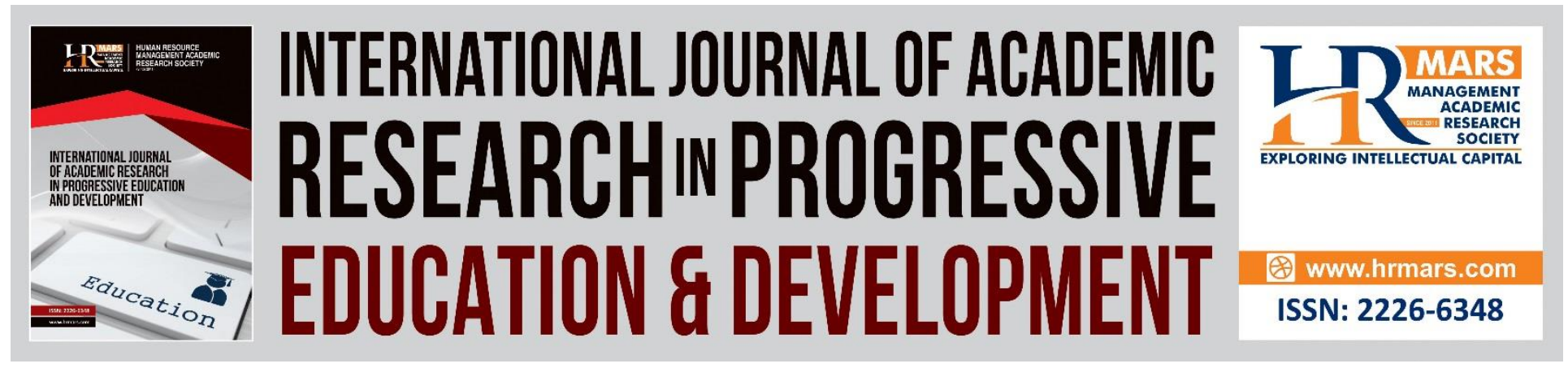

\title{
Attention Span Remediation of Attention Deficit Hyperactive Disorders (ADHD) Preschoolers with Music as Learning Background
}

Grace Annammal Piragasam, Abdul Razak Ismath Unoon

To Link this Article: http://dx.doi.org/10.6007/IJARPED/v7-i4/4799 DOI: 10.6007/IJARPED/v7-i4/4799

Received: 17 Sept 2018, Revised: 28 October 2018, Accepted: 03 Nov 2018

Published Online: 10 Nov 2018

In-Text Citation: (Piragasam \& Unoon, 2018)

To Cite this Article: Piragasam, G. A., \& Unoon, A. R. I. (2018). Attention Span Remediation of Attention Deficit Hyperactive Disorders (ADHD) Preschoolers with Music as Learning Background. International Journal of Academic Research in Progressive Education and Development, 7(4), 148-157.

Copyright: (C) 2018 The Author(s)

Published by Human Resource Management Academic Research Society (www.hrmars.com)

This article is published under the Creative Commons Attribution (CC BY 4.0) license. Anyone may reproduce, distribute, translate and create derivative works of this article (for both commercial and non-commercial purposes), subject to full attribution to the original publication and authors. The full terms of this license may be seen at: http://creativecommons.org/licences/by/4.0/legalcode

Vol. 7, No. 4, 2018, Pg. 148 - 157

http://hrmars.com/index.php/pages/detail/IJARPED

JOURNAL HOMEPAGE

Full Terms \& Conditions of access and use can be found at http://hrmars.com/index.php/pages/detail/publication-ethics 


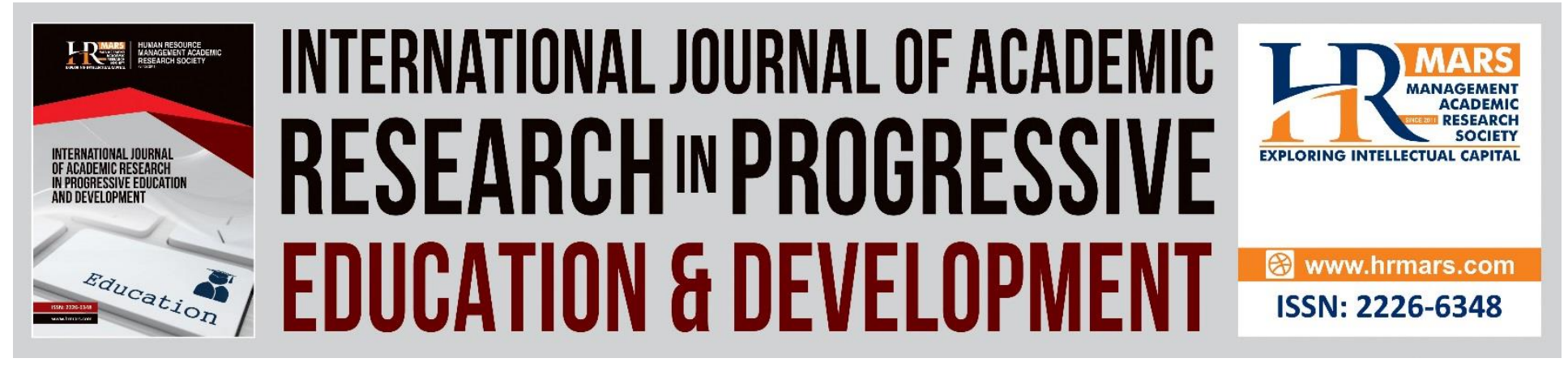

\title{
Attention Span Remediation of Attention Deficit Hyperactive Disorders (ADHD) Preschoolers with Music as Learning Background
}

\author{
Grace Annammal Piragasam \\ Department of Special Education, Universiti Pendidikan Sultan Idris, Malaysia. \\ Abdul Razak Ismath Unoon \\ Universiti Pendidikan Sultan Idris, Malaysia.
}

\begin{abstract}
The purpose of this study is to investigate effects of background music on the attention span of ADHD preschoolers using an A-B-A-B reversal design. Students' attention span were compared base on the ability to complete sole puzzle play. The attention span was firstly measured in terms of the accuracy of the puzzle pieces filled as well the speed t complete the puzzles play. The next analysis involves the occurrences of attention span in terms of students' behavior. A particular checklist served as the instrument to measure the occurrences of students' attention span behaviour. The total occurrence of targeted behaviours were counted and divided by the total number of intervals during each session lasting for thirty minutes. Participants in the study consist of two preschoolers diagnosed with Attention Deficit Hyperactive Disorder (ADHD). Participants attention span behavior were measured individually during each phase while solitary puzzle play commences. Participants were exposed to background music during the intervention phases as the intervention to their inattention deficits. Overall findings show that music effectively increases the attention span of ADHD preschoolers across time. The increasing mean scores were more significant during the second cycle of intervention phase for both participants. The finding implies that the use of music may serve as a remediating approach for intervening ADHD children. The findings also shows that the inattentive deficits of ADHD children may be promptly attended, thus the executive function of these children may effectively results in academic success and meaningful learning experiences.

Keywords: Special Education, Music, Attention Deficit Hyperactive Disorder, Attention Span, Solitary Play, Executive Function
\end{abstract}




\section{Introduction}

Early childhood education is a crucial phase for young children particularly children with special needs. The early years of children sets a foundation for their future. Children's readiness for academic, social and behavioural skills begins as early as their preschool stage. For most children, preschool provides fundamental experiences of learning environment on a social approach as teachers and their peers co-exist in the environment (Jones, Barnes, Bailey, \& Doolittle, 2017). There are various approaches to promote successful learning environment for preschoolers. Music particularly, has been used to stimulate a positive environment for preschoolers especially in the classroom settings. The use of music has been found to evoke positive behavior among preschoolers who exhibits inappropriate behavior affecting their academic skills and other domains of developments (Hallam \& Council, 2015).

Attention span among children contributes towards engaging children in learning and developing their aptitude. It is an important element in the classroom learning process to elevate cognitive, motor, physical and emotional development. The primary importance of attention span is to enable the child focus on task at a designated period of time (Diamond \& Lee, 2011). A child's sense of audacity and comprehension are also determined by attention spans. In short, attention spans help children to sustain in an activity without getting distracted (Nesbitt, Farran, \& Fuhs, 2015)

Preschoolers also comprise of special needs children and in this study it is zoomed to attention deficit hyperactive disorder (ADHD) children. ADHD children often fail to follow instructions and seem not to be listening when spoke directly (Christiansen, Hirsch, König, Steinmayr, Roehrle, 2015). They may demonstrate a reluctance to engage in tasks that require sustained mental effort or close attention to detail and may careless mistakes in their work.

The purpose of the study thus is to determine if background music affects the ability of selected children aged 3 to 5 to maintain focused attention to play. The scope of play in this research is also focused on the on task ability of preschooler's completing puzzle games accurately while task solving speed is observed.

\section{Literature Review}

Proponents of music field have extensively reported that music have positively affected ADHD children in their cognitive development for instances to be able to be more observant and academically better performed. For some students, music in the background helps to reduce distraction in the classroom such as unpleasant noise and even being highly sensitive to minute sound for instance pencil dropping. While these distractions are avoided, students are found to be more focused and attentive (Kim, \& Stegemann, 2016).

While various classroom activities are proposed to maximize children learning and development, child experts (Piaget, 1962; Vygotsky,1978) purported that exposure on play and physical activity are important for preschoolers. This is because preschool children obtain learning experiences and expression while playing takes place especially on how to regulate their emotions and behavior; as well as their cognitive skills and executive functions built. Play needs to be viewed as a cognitive process; not the end of learning, but the means of learning for preschoolers (Hoover \& Tunmer, 2017; Karmiloff-Smith, 2018). In other words, it is indicated that 

DEVELOPMENT

Vol. 7, No. 4, 2018, E-ISSN: 2226-6348 ๑ 2018 HRMARS

indicated that play allows a child the opportunity to experience and grow in their emotional regulation and the chance to engage in the give-and-take of social interaction with peers and older children (Bretherton, 1989; Howes \& Matheson, 1991; Sroufe, England, \& Elicker, 2016).

Research in the field of neuroscience demonstrates the positive impact of music on human being's attention span (Geist, Geist \& Kuznik, 2012). It was found that music stimulates the pre frontal cortex area which is related to attention span (Salimpoor, Zald, Zatorre, Dagher, \& McIntosh, 2015). However, the effect of music on the attention span of preschoolers needs exentensive research particularly on children diagnosed with ADHD.

Eren (2013) and Constantine (2015) for instance discussed on the effect of music among presechoolers with special needs. The findings can be infered that music potentially reduces anxiety level and streotypical behaviours of preschoolers with special needs. Several other research are covergent towards enhancing communication skills, attention span, as well as increasing emotion regulation (Gooding, 2011 ; Nguyen, 2014).

The ability of children to stay focused on a given task is vital for children success in a learning environment. The current study supports the importance of understanding attention as a multifaceted concept that relates to executive functions of preschoolers particulary among ADHD. Attention to a task allowed children to learn more easily, especially in a preschool setting.

\section{Methodology}

An A-B-A-B reversal design (Grace, Norfishah \& Abdul Halim, 2018; Rubin \& Babbie, 2016) was used to determine the efficacy of music in the background on preschoolers' attention span while they are engaged in solitary play. The particularresearch design allows for sequential application, comparison of effectiveness, and intra-subject replication of intervention effects (Barlow \& Hersen, 1984). The study included four phases that included A) baseline, B) back ground music, A) baseline, and B) background music procedures reinstated. Sessions occurred for a total of five weeks. During each session, student attention behaviour were observed and recorded in a checklist. Thus these sequential procedures can be inferred as idiographic (Harrington, 2013) which means a purpose to examine individual data on a gradual basis and to enable accurate estimation obtained to measure every single behavior of an individual.

The particular research design was chosen for several reasons. Firstly, the research is beneficial when a researcher intends to change certain individual behavior and wanting to document those incurred changes (Siegle, 2015). In this study, the design is tested on two ADHD preschoolers with the intended outcome is focused on their attention span while exposed to background music. Single subject study is also preferred in this study because the design does not require research subjects to be separated as control and experimental group as in experimental research. A single group may act as both control and experiment group alternately. Thirdly, single subject design is a scientific research which is now becoming commonly used in special education research (Cakiroglu, 2012).

The specific characteristics of the research subjects which a researcher intends to investigates makes it viable through the research design with the freedom to administer fewer number of samples (Cakirgolu, 2012) while the ethics are observed. Fourthly, single subject study design enables accurate evaluation pertaining the effectiveness of an intervention for average 
INTERNATIONAL JOURNAL OF ACADEMIC RESEARCH IN PROGRESSIVE EDUCATION AND DEVELOPMENT

Vol. 7, No. 4, 2018, E-ISSN: 2226-6348 ๑ 2018 HRMARS

samples of any population (Velicer \& Molenaar, 2013). The use of graphs enables the researcher to observe the changes impacted by the intervention on a number of samples.

\section{Participants and Setting}

The study included two children diagnosed with ADHD, age 6 who are currently placed in the special education integrated program classrooms. Consent was received from the Ministry of Education Malaysia (MOE), District Education Office of Larut Matang Selama, Taiping, as well the principal of the school after a meeting in which the study was thoroughly explained. The study took place in the environment where the child had been encountering problems in the school particularly in the classroom. A summary of the subjects' profile are as follows:

Subject A: This subject is a ADHD students with moderate severity. The preschooler is able to very minimal words while communicating with peers and teachers. Subject $A$ has the ability to understand instructions from teachers yet often fail to pay attention during lessons in the classrooms. Subject A often shields his ears while communicating with his peers indicating his discontentment to socialize. Subject $A$ does not favour tasks which require continuous mental force. This subject also occasionally needs teacher's assistance to accomplish certain routines such as tying shoe laces, feeding and toileting.

Subject B: Subject B is an ADHD and concomitant with autistic spectrum disorder. Subject $B$ faces difficulties to communicate especially when gestures are used. She produces incomplete sentences. Similarly, subject $B$ is often distracted in the classroom while being taught. As she also has the traits of autistic spectrum, subject $B$ tends to isolate herself. Subject $B$ rushes to complete the tasks given to her by teachers. However, the preschooler is able to manage her routine independently.

\section{Data Collection Procedures}

For the purpose of this study, the use of music in background served as the independent variable. Attention span served as dependent variables. Data collection occurred for three sessions each week. Thirty minute behaviour observations were completed during a continuous sole puzzle playing were conducted. The puzzle play were conducted to provide the ability of participants completing the task in speed and accurately as well.

Subsequently, observers recorded the occurrence and non-occurrence of attention behaviours in the classroom. Each 30-minute observation session was divided into 10-second intervals. Participants' attention span was recorded at the beginning of each 10 -second interval using standardized observation form. Exceptions included occasions in which a student leaves his or her seat with permission from the teacher. Permission from the teacher was defined as raising one's hand or approaching the teacher and receiving consent to engage in the behaviour (Barrish, Saunders, \& Wolf, 1969; Medland \& Stanchnik, 1972). Following each session, the total occurrence of targeted behaviours were counted and divided by the total number of intervals to determine the mean occurence of the attention span behaviour.

The checklist for measuring participants' attention span in this study was adapted from Mat Rabi \& Piragasam (2018). The authors have packaged an identification instrument for several disability categories including for observing ADHD children. The checklist which were adapted in this study have undergone the validation, pilot testing and reliability measurement (Cronbach Alpha 0.75-0.84 )to attain the rigorousness on the overall findings. 


\section{RESULTS}

The initial findings were focused in obtaining the accuracy and speed in completing the puzzle during each session. The descriptive data were obtained as the following. Figure 1, shows the task completion of research participants while playing puzzle as the task. The finding clearly shows that participant $A$ was able to complete more puzzle pieces during every session $(M=20.0)$ than participant $B(M=17.92)$. It is also evident that both participants' ability to complete task accurately in much shorter time were comparably much higher during both intervention phase, where music were played in the background. The maintenance phase shows that participants were able to sustain the task completion accurately within short period of time even when background music was not present.

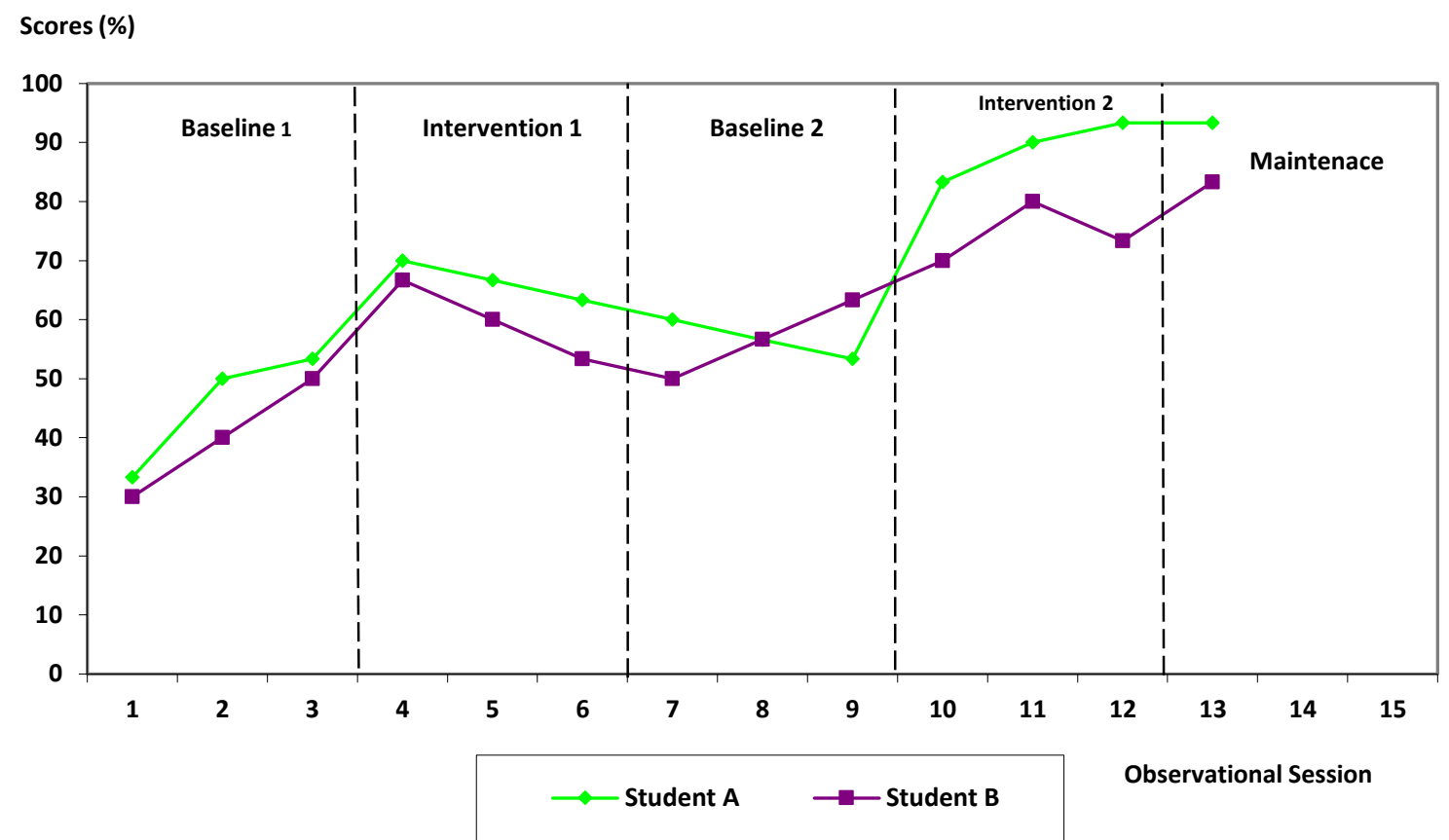

Figure 1. Puzzle completion speed in students during sole play

Table 1 shows the overall mean findings on the accuracy and speed for task completion. Participant A can be described as being able to perform better in terms of puzzle completion with higher score accuracy. Participant A also scores a higher overall mean in completing the puzzle pieces as in comparison to student B.

Table 1: Speed and accuracy overall mean in puzzle completion

\begin{tabular}{lll}
\hline Variable & & Mean (M) \\
\hline $\begin{array}{l}\text { Puzzle pieces completed in } \\
\text { accuracy }\end{array}$ & $\begin{array}{l}\text { Student A } \\
\text { Student B }\end{array}$ & 20 \\
& & \\
\hline Puzzle completion speed & Student A & 66.67 \\
& Student B & 59.74 \\
& & \\
\hline
\end{tabular}


INTERNATIONAL JOURNAL OF ACADEMIC RESEARCH IN PROGRESSIVE EDUCATION AND DEVELOPMENT

Vol. 7, No. 4, 2018, E-ISSN: 2226-6348 @ 2018 HRMARS

The mean differences will be analyzed further in the next section. Table 2 show the findings of paired sample t-test analysis between Baseline 1 and Intervention. Comparison analysis of mean between two phases may be considered as pretest and posttest especially when small size samples are concerned (Chua, 2014; Salkind, 2010).

The results describe that mean scores of attention span for participant $A$ in the pretest (Baseline $1 M=60.33 \%$ ) as in comparison with posttest (Intervention $1 M=74.33 \%$ ). The finding significantly shows that participant $A$ attention span during the intervention 1 phase as music was treated in the background were not significant (t-1.031, $p>0.05$ ). Therefor the mean scores were not significant to manifest the effect of music during task execution.

Table 2. Paired sample t-test to compare attention span scores between baseline 1 and intervention 1 for Student A

\begin{tabular}{|c|c|c|c|c|c|c|c|}
\hline \multirow[t]{2}{*}{ Construct } & \multirow[t]{2}{*}{ Paired Sample } & & \multirow[t]{2}{*}{$\mathrm{N}$} & \multirow{2}{*}{$\begin{array}{l}\text { Man } \\
\text { Score } \\
(\%)\end{array}$} & \multirow{2}{*}{$\begin{array}{l}\text { Standar } \\
\mathrm{d} \\
\text { Deviati } \\
\text { on }\end{array}$} & \multicolumn{2}{|l|}{ t-test } \\
\hline & & & & & & $\mathrm{t}$ & sig \\
\hline Attention & Baseline 1 (pretest) & & 3 & 60.33 & 7.51 & -1.031 & 0.41 \\
\hline $\begin{array}{l}\text { span } \\
\text { score }\end{array}$ & $\begin{array}{l}\text { Intervention } \\
\text { (posttest) }\end{array}$ & 1 & 3 & 74.33 & 16.07 & & \\
\hline
\end{tabular}

Table 3 displays the t-test analysis of participant attention span during the second cycle of baseline 2 and intervention2 phases. The results a significant difference in the mean score between the phases with the increase of attention span during intervention phase 2 (I2 $\mathrm{M}$ $=90.0 \%$ ) in comparison to pretest/baseline phase 2 (B2 $M=64.67 \%$ ) dan posttest/intervention 1 $(90.00 \%)$ with a variance of $25 \%$. The particular result shows background music significantly increases student $A^{\prime}$ 's attention span ( $p<0.05$ iaitu 0.021).

Table 3. Paired sample t-test to compare attention span scores between baseline 2 and intervention 2 for Student A

\begin{tabular}{|c|c|c|c|c|c|c|}
\hline \multirow[t]{2}{*}{ Construct } & \multirow[t]{2}{*}{ Paired Sample } & \multirow[t]{2}{*}{$\mathrm{N}$} & \multirow{2}{*}{$\begin{array}{l}\text { Mean } \\
\text { Score (\%) }\end{array}$} & \multirow{2}{*}{$\begin{array}{l}\text { Standard } \\
\text { Deviation }\end{array}$} & \multicolumn{2}{|l|}{ t-test } \\
\hline & & & & & $\mathrm{t}$ & sig \\
\hline Attention & Baseline 2 (pretest) & 3 & 64.67 & 9.61 & -6.74 & 0.021 \\
\hline span score & Intervention 2 (posttest) & 3 & 90.00 & 3.46 & & \\
\hline
\end{tabular}

Table 4 displays the mean difference in the attention span of participant $B$ during baseline 1 dan intervention 1 phases. The mean difference are significant $(t-11.50, p<0.05)$ with the increase of attention span for participant B during the Intervention 1 phase $(I 1 M=81.33 \%)$ in comparison with Baseline 1 phase (BI1 $M=81.33 \%)$. 
INTERNATIONAL JOURNAL OF ACADEMIC RESEARCH IN PROGRESSIVE EDUCATION AND DEVELOPMENT

Vol. 7, No. 4, 2018, E-ISSN: 2226-6348 @ 2018 HRMARS

Table 4. Paired sample t-test to compare attention span scores between baseline 1 and intervention 1 for Student B

\begin{tabular}{|c|c|c|c|c|c|c|}
\hline \multirow[t]{2}{*}{ Construct } & \multirow[t]{2}{*}{ Paired Sample } & \multirow[t]{2}{*}{$\mathrm{N}$} & \multirow{2}{*}{$\begin{array}{l}\text { Mean } \\
\text { Score (\%) }\end{array}$} & \multirow{2}{*}{$\begin{array}{l}\text { Standard } \\
\text { Deviation }\end{array}$} & \multicolumn{2}{|l|}{ t-test } \\
\hline & & & & & $\mathrm{t}$ & sig \\
\hline Attention & Baseline 1 (pretest) & 3 & 58.33 & 9.71 & - & 0.007 \\
\hline $\begin{array}{l}\text { span } \\
\text { score }\end{array}$ & Intervention 1 (posttest) & 3 & 81.33 & 6.51 & 11.50 & \\
\hline
\end{tabular}

Meanwhile table 5 , shows a continuous significant effect of music ( $t-4.09, p<0.05$ ) in the Intervention 2 phase $(12=85.67 \%)$. In fact records a highest mean score in the attention span of participant $B$ throughout the study.

Table 5. Paired sample t-test to compare attention span scores between baseline 2 and intervention 2 for Student B

\begin{tabular}{|c|c|c|c|c|c|c|}
\hline \multirow[t]{2}{*}{ Construct } & \multirow[t]{2}{*}{ Paired Sample } & \multirow[t]{2}{*}{$\mathrm{N}$} & \multirow{2}{*}{$\begin{array}{l}\text { Mean } \\
\text { Score } \\
(\%)\end{array}$} & \multirow{2}{*}{$\begin{array}{l}\text { Standard } \\
\text { Deviation }\end{array}$} & \multicolumn{2}{|l|}{ t-test } \\
\hline & & & & & $\mathrm{t}$ & \\
\hline Attention & Baseline 2 (pretest) & 3 & 66.67 & 9.71 & -4.09 & 0.032 \\
\hline span score & Intervention 2 (posttest) & 3 & 85.67 & 4.04 & & \\
\hline
\end{tabular}

The data shows that participant records the highest mean score of attention span and reported during the intervention 2 phase. The overall study shows the effect of music on ADHD student attention span with the exception for participant A during the first cycle of intervention. However, the increase in the attention span gradually takes effect, manifesting the effect of music on ADHD student over time.

\section{Discussion}

The use of music plays an important role in the early development phases of a child. Attention span is an important element to elevate the executive function of a child, thus it is necesary to assist preschoolers with ADHD to acquire self-regulation over their deficits of attention span. This research adds to the information that preschool teachers, and parents on how to best prepare an ADHD child for kindergarten. The unique need of preschoolers has to be addressed and how ADHD children respond to background music. Future research with a larger participant base, and different types of disability would be beneficial.

\section{References}

Chua, Y. P. (2014). Kaedah penyelidikan. $3^{\text {rd }}$ Edition. Shah Alam: McGraw-Hill Education.

Constantin, F. A. (2015). Emotional Effects of Music Therapy on Children with Special Needs. Journal Plus Education, Vol XII A - SPECIAL ISSUE (2015), pp. 178- 183. Dimuat turun pada 6 Ogos, 2016, retrieved from http://web.b.ebscohost.com.ezpustaka.upsi.edu.my/.

Creswell, J. W., \& Creswell, J. D. (2017). Research design: Qualitative, quantitative, and mixed methods approaches. Sage publications. 
INTERNATIONAL JOURNAL OF ACADEMIC RESEARCH IN PROGRESSIVE EDUCATION AND DEVELOPMENT

Vol. 7, No. 4, 2018, E-ISSN: 2226-6348 @ 2018 HRMARS

Diamond, A., \& Lee, K. (2011). Interventions shown to aid executive function development in children 4 to 12 years old. Science, 333(6045), 959-964.

England, M., \& Sroufe, L. A. (1992). Predicting peer competence and peer relationships in childhood from early parent-child relationships. Family-peer relationships: Modes of linkage, 77.

Eren, U., Deniz. J., \& Düzkantar, A. (2013). The Effectiveness of Embedded Teaching through the Most-to-Least Prompting Procedure in Concept Teaching to Children with Autism within Orffbased Music Activities. Educational Sciences: Theory \& Practice, 13(3) : 1877-1885. Dimuat turun pada 20 Julai, 2016, retrieved from http://web.b.ebscohost.com.ezpustaka.upsi.edu.my/.

Geist, K., Geist, E. A., \& Kuznik, K. (2012). The Patterns of Music : Young Children Learning Mathematics through Beat, Rhythm, and Melody. Young Children, January 2012 : 74 - 79. Dimuat turun pada 11 Oktober, 2016, retrieved from https://www.naeyc.org/files/yc/file/201201/Geist Patterns of Music Jan012.pdf.

Gooding, L. F. (2011). The effect of a music therapy social skills training program on improving social competence in children and adolescents with social skills deficits. Journal of music therapy, 48(4), 440-462.

Hallam, S., \& Council, M. E. (2015). The power of music: A research synthesis of the impact of actively making music on the intellectual, social and personal development of children and young people. International Music Education Research Centre (iMerc).

Hanna Christiansen, Oliver Hirsch, Anika König, Ricarda Steinmayr, Bernd Roehrle, (2015) "Prevention of ADHD related problems: a universal preschool program", Health Education, Vol. 115 Issue: 3/4, pp.285-300, retrieved from https://doi.org/10.1108/HE-03-2014-0040.

Hoover, W. A., \& Tunmer, W. E. (2017). Cognitive and linguistic factors in learning to read. In Reading acquisition(pp. 175-214). Routledge.

Jones, S. M., Barnes, S. P., Bailey, R., \& Doolittle, E. J. (2017). Promoting social and emotional competencies in elementary school. The Future of Children, 49-72.

Karmiloff-Smith, A. (2018). Précis of Beyond modularity: A developmental perspective on cognitive science. In Thinking Developmentally from Constructivism to Neuroconstructivism(pp. 64-94). Routledge.

Kim, J., \& Stegemann, T. (2016). Music listening for children and adolescents in health care contexts: A systematic review. The Arts in Psychotherapy, 51, 72-85.

Mat Rabi N. \& Piragasam G.A. (2018), Instrumen saringan dan pengesanan kanak-kanak berkeperluan khas. Read Resources: Negeri Sembilan, Malaysia.

Nesbitt, K. T., Farran, D. C., \& Fuhs, M. W. (2015). Executive function skills and academic achievement gains in prekindergarten: Contributions of learning-related behaviors. Developmental psychology, 51(7), 865.

Nguyen, A. (2014). Using Classical Music to Increase Productivity in Elementary School Students with Attention Deficit Hyperactivity Disorder.

Piragasam G.A, , Mat Rabi N.\& Masnan, A.B. (2018) The use of sensory balls in the classroom: Effects on behavioural and academic functioning of students with learning disabilities. International Journal of Academic Research in Business and Social Sciences, 8 (4), 1143-1166. 
INTERNATIONAL JOURNAL OF ACADEMIC RESEARCH IN PROGRESSIVE EDUCATION AND DEVELOPMENT

Vol. 7, No. 4, 2018, E-ISSN: 2226-6348 @ 2018 HRMARS

Salimpoor, V. N., Zald, D. H., Zatorre, R. J., Dagher, A., \& Mclntosh, A. R. (2015). Predictions and the brain: how musical sounds become rewarding. Trends in Cognitive Sciences, 19(2), 86-91.

Salkind, N. J. (2010). Encyclopedia of research design Thousand Oaks, CA: SAGE Publications, Inc. doi: $10.4135 / 9781412961288$. 